\title{
Formative Evaluation of the Nursing Program at a University in the South of Brazil: Technological Tool to the Approach of the Unified Health System*
}

\author{
Marta Lenise do Prado1, Ana Karolliny Testoni', Silvana Silveira Kempfer ${ }^{1}$, Fabiane Ferraz ${ }^{2}$, \\ Christiny Regina Lopes ${ }^{1}$, Mariely Carmelina Bernardi ${ }^{1}$ \\ ${ }^{1}$ Department of Nursing, Federal University of Santa Catarina, Florianópolis, Brazil \\ ${ }^{2}$ Department of Nursing, University of the Extreme South of Santa Catarina, Criciúma, Brazil \\ Email: testoni@hotmail.com \\ Received September 2013
}

\begin{abstract}
Background: The educational evaluation focused on the critical training, creative and reflective is wanted on the need for competent nursing professionals, acting effectively to the present challenges in the context in which the Health System performs in Brazil. Aims: Identify how the formative assessment process is expressed in the syllabus of Nursing Federal University of Santa Catarina and in what features it is configured as a tool of educational technology that promotes the approach with the Unified Health System. Method: Qualitative research, exploratory and descriptive in documentary base. Data were collected from May to December 2012 and analyzed descriptively, from the perspective of the proposed evaluation on the National Curriculum Guidelines/ Nursing. Results: There were 23 types of evaluation on 33 teaching plans. The category that emerged was: "Expression of competence evaluation on plans of teaching on nursing course", which presents the different types of evaluation related to three dimensions: knowledge, skills and attitudes. Conclusion: Perceives a movement of structural changes in some disciplines, making the evaluation exit of the traditional matrix to a constructive matrix, characterized as a technological tool that enhances professional development focused on the Health System.
\end{abstract}

\section{Keywords}

Education; Nursing; Educational Measurement; Competency-Based Education

\section{Introduction}

Higher education in Brazil for a few years undergoes changes in its fundamental basis. The focus of educational practice does not include the reductionist view anymore of the mass training and the contents spill randomly so

\footnotetext{
"Study derived from the macro-project "Practice critical-reflective and creative on training in Nursing". Funded by the National Council for Scientific and Technological Development-CNPq. Brazil.

How to cite this paper do Prado, M.L., et al. (2014) Formative Evaluation of the Nursing Program at a University in the South of Brazil: Technological Tool to the Approach of the Unified Health System. Open Journal of Social Sciences, 2, 1-6. http://dx.doi.org/10.4236/iss.2014.22001
} 
that the student has the obligation to assimilate it. What is sought is to assume a personalized posture, individualized, providing content to be understood by students in a pleasant way, critically and creatively, and effectively transforming into knowledge themselves.

The National Board of Education, establishes the National Curriculum Guidelines (NCG) for graduation courses, and have aimed out that these guidelines be models of the transformation of higher education in Brazil, breaking the teaching characterized process by verticalization and transmission of knowledge, to promote a new conduct, based on the formation of the critical professionals and ready to work in society [1].

In this context, the evaluation must be assumed as a tool for understanding the learning stage in which the student is in order to make enough and acceptable decisions to proceed in their learning process [2]. The evaluation should enable the formation of the ethical and humanistic aiming the values and attitudes, aiming at increasing the academic autonomous and permanent improvement, regulated in promoting learning modes that can contribute effectively in the training for citizenship [1].

This evaluating process is a technological tool when it understands Educational Technology as a systematic set of knowledge that enables the planning, execution, control and monitoring, involving all formal and informal educational process, in which it reveals the know-how and know use the knowledge and equipment in all everyday situations. To apply an Educational Technology of process or product is necessary that the teacher (health care professional) be a facilitator of the teaching-learning, and the student an active participant in this process that both use the creative consciousness, sensitivity and creativity in order to promote the construction and reconstruction of knowledge [3].

Face to the Brazilian national context, the Department of Nursing of the Federal University of Santa Catarina (UFSC), seeking to incorporate the National Curriculum Guidelines of graduating Nursing (NCG/Nurse), initiated a movement to adapt curriculum in order to attend the new determinations for health training. So that these modifications aimed the development of the nurse with critical skill, creative and reflective, generalist and prepared to act with the demands and principles of the Unified Health System (SUS) [4].

In this context, the Pedagogical Project Course (PPC) Nursing UFSC understands the evaluation as a strategy that involves not only knowledge measurement in specific fields of knowledge, but goes further by proposing personal skills through individual and collective projects to make the overcome of the fragmentation of knowledge possible, so that this movement requires a new logic, in which both the teacher and the student act simultaneously as key elements in the construction of knowledge [5]. Thus, this study aims: identify how the formative evaluation process is expressed in the syllabus of Nursing UFSC and in what aspects it is configured as a tool of educational technology that promotes the approach with the Unified Health System.

\section{Methodology}

Exploratory descriptive research in documentary basis of the qualitative nature, occurred on the graduation Nursing Course, Federal University of Santa Catarina, Brazil, that is structured with a minimum time for completion of 10 semesters, giving a total workload of 4788 hours/class.

Data were collected in the period from May to December of 2012, by requesting formal authorization of the course teachers. Organized on table of the Microsoft Excel and analyzed descriptively, 33 Plans Teaching compulsory subjects. From descriptive analysis emerged the category "Expression of the competence evaluation on plans of teaching of nursing".

The study derives from macro project "The critical-reflective practice and creative training in Nursing", which was submitted to the Ethics Committee in Researches of UFSC, getting approval under Protocol. 1.942/ 2011.

\section{Results}

\section{Expression of Evaluation of Competence in the Syllabus of Nursing}

The Brazilian National Curricular Guidelines in its content, beyond define the use of the type summative and formative evaluation, proposes orientations for curriculum structuring integrating general and specific competencies, that several areas should maintain and develop in their pedagogical projects [1].

The types of assessment identified in the 33 Education Plans (Table 1) were analyzed from the perspective of the proposed evaluation NCG/Nurse, which searches the development and improvement of skills by the student, 
related to three dimensions: knowledge, skills and attitudes.

It is possible observe that among the items expressed in the plans, written test is evidenced as the primary way to assess knowledge. In the field of competences to the development of attitudes were described mainly the items of participation and attendance, while, seminars and evidence or theoretical-practical activities are identified in evaluation skills.

Note that there were no evaluation procedures that refer only to the development of skills, since the items expressed in this dimension, are also considered in other dimensions. Most of evaluative proposals encompasses more than one dimension of competence, among which stood out for seminars and theoretical-practical tests as those that encompass the three dimensions.

Table 1. Distribution of evaluation of the described competences in the Plans Teaching of the Nursing Course at the Federal University of Santa Catarina, 2013.

\begin{tabular}{|c|c|c|}
\hline $\begin{array}{l}\text { Dimensions of Evaluation of the } \\
\text { Competence }\end{array}$ & Type of Evaluation & Absolute Number \\
\hline \multirow{9}{*}{ Knowledge } & Written test & 17 \\
\hline & $\begin{array}{l}\text { Report of readings: book (2), movie (1), thesis (1), } \\
\text { clinical study (2), abstract (1), works ( } 8)\end{array}$ & 15 \\
\hline & Final Report & 4 \\
\hline & Reports throughout the semester & 3 \\
\hline & Project & 2 \\
\hline & Theoretical foundation & 1 \\
\hline & Field diary & 1 \\
\hline & Screenplay of anamnesis & 1 \\
\hline & Total & 44 \\
\hline \multirow{8}{*}{ Skills } & Seminary & 8 \\
\hline & Test theory-practice & 7 \\
\hline & Activity theory-practice & 5 \\
\hline & Synthesis reflective & 2 \\
\hline & Portfolio & 1 \\
\hline & Socialization & 1 \\
\hline & Planning applied & 1 \\
\hline & Total & 25 \\
\hline \multirow{9}{*}{ Attitudes } & Participation & 12 \\
\hline & Attendance / frequency & 7 \\
\hline & Punctuality & 4 \\
\hline & Self-evaluation & 3 \\
\hline & Interest & 2 \\
\hline & Creativity & 1 \\
\hline & Looking for additional sources & 1 \\
\hline & Complementary activities & 1 \\
\hline & Total & 31 \\
\hline
\end{tabular}

Source: Teaching plans Nursing Course UFSC, 2012. 
It was found that five Teaching Plans do not have scores and two describe the evaluation of attitude, but they do not have score for that item at the final notes.

In this context, there are some processes in the plans of teaching which we refer to the formative evaluation, considering the attitudes, skills, individual and collective [6]. However, it is clear that inconsistencies are still found related to the evaluation process, because most evaluations appears strongly linked to theoretical tests and ratings of content, expressed in weight and note, and do not point to the other parameters of competences.

The concept of competence understood as a result of the relationship of knowledge, skill and attitude is a result of the evolutionary path of several management theories that started in the 70s, Being the set of capabilities "that justify a high performance, believing that the best performances are based on the intelligence and personality of the people" [7]. Incorporates the agenda of universities from the 90s, at moment it strengthened the idea that employees, in addition to possessing technical knowledge, should add other skills to the full development of their activities-purposes [8].

\section{Discussion}

Thinking on evaluation in the non-traditional context means expanding their scope and consider other elements in the process of teaching-learning, including their theoretical conceptions. The evaluation assumes the centrality of this process because it involves addition of faculty-student ratio, also the curriculum, the educational institution, the management and the educational system [9].

The presented results reinforce the need for reflection on the centrality of evaluation processes with a normative/summative aspect, in other words, traditional on the higher education, pointing to the hegemony of activities that seek to measure the knowledge acquired, usually by means of written tests. From the perspective of normative evaluation or summative, this structure is understood as final evaluation that determines achieving goals, aiming certify acquisition in relation to third parties, characterized by comparison, the punctuality of the evaluative moment, which configures the evaluation as static activity and final $[6,10]$.

The predominance of assessments that measure the knowledge demonstrates that the majority of evaluations performed on the course still remain tied to assigning grades and measurement of cognitive skills at the expense of skills and attitudes provided in conjunction. Remember and corroborates the statement that "the concern of the reviewer is to point and try to explain results obtained by the student, to start a new period evaluative" [11]. The evaluation refers to the past, ending up in assigning value judgments and justifications for it, to the student to a certain time [11].

Formative evaluation, however, is used as a tool to guide the necessary adjustments during the educational process, seeking to achieve the goals objectified [10]. Presupposes the moment of evaluation as an element of the educational process, in which the evaluation as well as being continuous, is seen as a tool for potential changes in teaching and learning. In formative evaluation, the teacher should not allow the results of periodic tests, usually classificatory character, are overvalued at the expense of their daily observations of diagnostic character [12].

The teacher working in an interactive dynamic realizes the participation and productivity of each student, considering "all formative assessment practice continuous wish to contribute to improving the learning in progress, whichever of the context and the extent of differentiation of the teaching" [6].

By incorporating formative evaluation makes sense the presence of items based on participation, attendance and student creativity, gain meaning the subjective dimensions, as expressions of learning that are not confined to the time of the tests, but permeate the whole process of teaching. Thus, evaluation is enhanced, because it assesses the development of competence by students in all its dimensions, not overvaluing the knowledge.

On the other hand, traditional practices back to the certificate or evidential character experienced by student on the scholar period, agglutinating and demonstrating results and mentioning attitudinal responses in order to explain and justify the achievement of objectives in a time and space. "In that sense, the assessment back to the past, reporting and explaining the present" [11].

The results give evidence that there is a movement of structural changes in some subjects in relation to the evaluation, which leaves the traditional matrix, where the attributes were evaluated by means of "measuring" the knowledge and judgment of value, for a constructivist matrix, linked to the subjective aspects of the teachinglearning process, including the negotiation and democratic attitude that must be established between the subjects involved. The health training from the principles of the NHS is premised on the understanding of subjectivity 
that is always present in a democratic relationship in the teaching-learning where the teacher must have clarity about their own performance and evaluation [13].

The articulation of the subjects involved in the evaluation processes is another important aspect to be considered. When looking at the items that comprise the assessment of education plans, draws attention to the amount of activities and their various denominations. The clarity of what is proposed by teachers and educational institution is important "as an expression of a process of shared work product and not as punctual and artificialized, evaluation will gain more political significance and technical (exactly in this order), being consistent with the formative role that was expected" [14].

When analyzing the data we can perceive that there is a positive movement in the Course of Nursing UFSC by consider other dimensions of competence that go beyond the knowledge. This characteristic approaches the plans of the teaching to the desired profile in professionals who will work in the National Health System, because the complexity of healthcare work need skills and attitudes that promote group work, a good interpersonal relationship between professionals and these with the community, among many other aspects that permeate comprehensive care and expanded clinic, which need to be exercised over training.

This scenario that objective achieve in higher education aims at training for life in society, permitting everyone involved one process that leads to a supportive and fair living, therefore proposed the formation of citizens and the consolidation of citizenship in order to build a more democratic society [12].

On the motion the formation of competencies, it is essential discuss extensively the role of evaluation in the setting of higher education. As a technological tool, formative evaluation enhances the professional development of students. However, if understood as the final activity of the educational process, is limited to justify behaviors, losing the opportunity to transform students into better citizens.

\section{Conclusion}

Due to a historical context focused on the evaluation in traditional matrix, it appears that the examined course, there is still a predominance of cognitive instruments that assess students quantitatively, linking evaluation to content and disciplinary knowledge. However, some plans of teaching have an adaptation movement to Pedagogical Project of Course in a perspective of formative evaluating, valuing the participation, motivation, performance and involvement of the group, stands out the potential of students for citizenship. This aspect can be recognized as a tool of educational technology, that approaches and assists in the training of professionals, capable of operating on the SUS of reflectively form, critically and creatively.

\section{Acknowledgements}

The Research Group on Nursing Education and Health, Federal University of Santa Catarina, concrete example of mobilization and encouragement of collective labor from the congregation of faculty researchers, academics and interested professionals.

The National Council for Scientific and Technological—CNPq/Ministério de Ciência e Tecnologia—Brasil for financial support.

\section{References}

[1] Brasil. Ministério da Educação e do Desporto (1997) Conselho Nacional de Educação. Parecer CNE No 776/97.

[2] Luckesi, C.C. (2000) Avaliação da aprendizagem escolar. In: Luckesi, C.C., Ed., 10th Edition, Avaliação do aluno: A favor ou contra a democratização do ensino? Cortez, São Paulo, 60-84.

[3] Nietsche, E.A., Backes, V.M.S., Colomé, C.L.M., Ceratti, R.N. and Ferraz, F. (2005) Education, care and management technologies: A reflection based on nursing teachers' conception. http://dx.doi.org/10.1590/S0104-11692005000300009

[4] Brasil. Conselho Nacional de Educação, Câmara da Educação Superior (2001) Parecer nº 3, de 7 de novembro de 2001.

[5] Barbosa, S.F.F., Amante, L.N., Boehs, A.E. and Andrade, S.R. (2011) Guia dos estudantes do curso de graduação em enfermagem. Editora Universidade Federal de Santa Catarina, Florianópolis.

[6] Perrenoud, P. (1999) Avaliação: da excelência à regulação das aprendizagens-Entre duas lógicas. Artes Médicas, Porto Alegre. 
[7] Fleury, M.T.L. and Fleury, A. (2001) Construindo o conceito de competência. http://dx.doi.org/10.1590/S1415-65552001000500010

[8] Ruthes, R.M. and Cunha, I.C.K.O. (2008) Entendendo as competências para aplicação na enfermagem. http://dx.doi.org/10.1590/S0034-71672008000100017

[9] Sobrinho, J.D. (2010) Avaliação e transformações na educação superior brasileira (1995-2009): Do provão ao SINAES. http://dx.doi.org/10.1590/S1414-40772010000100011

[10] Arredondo, S.C. and Diago, J.C. (2009) Avaliação educacional e promoção escolar. Ibpex, Curitiba and Unesp, São Paulo.

[11] Hoffmann, J. (2005) Avaliar para promover: As setas do caminho. 7th Edition, Mediação, Porto Alegre.

[12] Sobrinho, J.D. (2008) Avaliação educativa: Produção de sentidos com valor de formação. http://dx.doi.org/10.1590/S1414-40772008000100011

[13] Laluna, M.C. and Ferraz, C.A. (2009) Os sentidos da prática avaliativa na formação de enfermeiros. http://dx.doi.org/10.1590/S0104-11692009000100004

[14] Sordi, M.R.L. and Ludke, M. (2009) From the evaluation of learning to institutional evaluation: necessary lessons. http://dx.doi.org/10.1590/S1414-40772009000200005 